E-JURNAL EKONOMI DAN BISNIS UNIVERSITAS UDAYANA
Available online at https://ojs.unud.ac.id/index.php/EEB/index
Vol. 10 No. 5, Mei 2021, pages: 491-500
e-ISSN: 2337-3067

\title{
DAMPAK MEDIA SOSIAL PADA KINERJA UMKM DI KOTA BANDAR LAMPUNG
}

\section{Anggun Yustia Arinda $\mathbf{T}^{\mathbf{1}}$}

\begin{tabular}{l}
\multicolumn{1}{c}{ Article history: } \\
\hline Submitted: 10 Februari 2021 \\
Revised: 18 Maret 2021 \\
Accepted: 1 April 2021 \\
\hline
\end{tabular}

Keywords:

Social media;

UMKM;

Survey;

Performance;

\section{Kata Kunci:}

Media Sosial;

UMKM;

Survey;

Kinerja;

\section{Koresponding:}

Universitas Lampung,

Lampung, Indonesia

Email:

arinda1011.mie2019@gmail.c om
The use of information technology developments is widely used to develop businesses, both from companies and from individuals. The rapid development of digital technology over the last few years has had a major impact on various existing economic actors, including SMEs, to survive and continue to compete. This study examines the impact of social media on the performance of SMEs in the city of Bandar Lampung. This study uses primary data with a direct survey method involving 100 respondents of SME business actors with various industries in the city of Bandar Lampung. The data collected will be analyzed using descriptive quantitative and qualitative descriptive methods using various descriptive statistical tools and single frequency tables and cross frequency tables. widely used by UKM Bandar Lampung City with a percentage rate of $82.70 \%$ with a time of 3-4 hours a day. The impact of the use of social media on the performance of SMEs has a positive effect on sales performance by $59.2 \%$, marketing performance by $59.2 \%$, and sales interactivity becomes easier by $72.2 \%$. However, social media is still less influential in increasing the number of employees because only $38.8 \%$ is less than $50 \%$.

Abstrak
Pemanfaatan perkembangan teknologi informasi banyak sekali
digunakan untuk mengembangkan bisnis, baik dari perusahaan maupun
dari individu. Perkembangan teknologi digital yang cukup pesat selama
beberapa tahun terakhir memberikan dampak besar pada berbagai pelaku
ekonomi yang ada, termasuk para pelaku UMKM untuk bertahan dan
terus bersaing. Penelitian ini mengkaji dampak adanya media sosial
terhadap kinerja UMKM di Kota Bandar Lampung. Penelitian ini
menggunakan data primer dengan metode survei secara langsung terdahap
100 responden pelaku usaha UMKM dengan berbagai industri di Kota
Bandar Lampung. Data yang dikumpulkan dianalisis dengan metode
deskriptif kuantitatif dan deskriptif kualitatif dengan memanfaatkan
berbagai peralatan statistik deskriptif dan tabel-tabel frekuensi tunggal
dan tabel frekuensi silang. Berdasarkan hasil analisis deskriptif kuantitatif
dan deskriptif kualitatif penelitian ini menemukan bukti empiris bahw
WhatsApp menjadi media sosial yang paling banyak digunakan oleh
pelaku UMKM Kota Bandar Lampung dengan tingkat persentase sebesar
82,70\% dengan waktu 3-4 jam dalam sehari. Dampak penggunaan media
sosial terhadap kinerja UMKM berpengaruh positif terhadap kinerja
penjualan sebesar sebesar 59,2\%, kinerja pemasaran sebesar 59,2\%, dan
interaktivitas penjualan menjadi lebih mudah sebesar 72, 2\% . Namun,
media sosial masih kurang berpengaruh terhadap peningkatan jumlah
pegawai karena hanya 38,8\%.




\section{PENDAHULUAN}

Krisis ekonomi yang menimbulkan tumbangnya perekonomian Indonesia berakibat pada usaha-usaha berskala termasuk industri, perdagangan, serta jasa yang menghadapi stagnasi hingga terhenti. Tetapi Usaha Mikro, Kecil serta Menengah (UMKM) bisa bertahan serta pembangkit keterpurukan ekonomi akibat krisis moneter pada berbagai sektor ekonomi, apalagi jumlahnya bertambah sangat pesat. UMKM menjadi tulang punggung ekonomi kerakyatan yang sanggup merentas kemiskinan serta penyerapan tenaga kerja. UMKM mampu menghasilkan lapangan pekerjaan lebih besar dibanding sektor usaha lain.

Permasalahan utama yang dialami oleh UMKM merupakan pemasaran menggunakan cara konvensional yang membutuhkan biaya besar, seperti membuka cabang industri, turut mengikuti pameran, membuat serta penyebaran brosur. Revolusi industri yang dihadapi puncaknya pada saat ini dengan lahirnya teknologi digital yang berakibat masif terhadap hidup manusia di seluruh dunia. Pertumbuhan teknologi digital yang lumayan pesat sepanjang beberapa tahun terakhir memberikan dampak yang cukup besar pada pelaku ekonomi yang ada, khususnya para pelaku UMKM. Pemakaian media sosial dalam UMKM sanggup meningkatkan pangsa pasar serta volume penjualan sampai 100\% apabila mampu melaksanakan pembaharuan informasi penjualan setiap harinya (Priambada, 2015).

Sebagian besar studi terdahulu terpaut pemakaian media sosial oleh UKM di Indonesia menggunakan riset kualitatif antara lain ialah metode studi kasus (Utami \& Purnama, 2012), deskriptif kualitaatif dengan menguasai fenomena yang dirasakan pelaku UMKM (Ardiyanto, 2018). Riset Deskriptif Observasional menimpa implementasi media sosial terhadap pengembangan UMKM (Purwidiantoro \& Hadi, 2016), manfaat penggunaan media sosial (Priambada, 2015) serta media sosial sebagai media promosi (Siswanto, 2013).

Riset tedahulu menganalisis manfaat penggunaan media sosial belum secara kuantitatif dan belum mendalam. Maka dengan semakin berkembangnya digitalisasi UMKM untuk mendongkrak penjualan yang di dampingi dengan semakin berkembangnya teknologi sehingga membuat pelaku usaha untuk memasarkan produk, yang semula hanya dari mulut ke mulut atau sekedar memasang iklan di dalam kota, kini beralih menjadi pedagang online dengan menjangkau pangsa pasar seluruh Indonesia bahkan luar negeri. Meningkatnya pemakaian teknologi informasi ini didukung oleh sebagian aspek, antara lain bayaran murah, pengguna smart phones yang terus menjadi bertambah, penyimpanan informasi secara online (cloud computing), serta semakin banyaknya layanan digital yang ada dengan Aplikasi as a Service( SaaS ) (Assinform, 2011 dalam Cesaroni \& Consoli, 2015). Media Sosial dapat menjadi peluang untuk pelaku bisnis guna tingkatkan inovasi dengan metode berbagi (sharing), bekerjasama (collaboration) serta berkreasi bersama (co-creation) (Vasileidadou \& Missler- Behr, 2001; Choi et al., 2014)

Penelitian ini bertujuan untuk menganalisis apakah media sosial berdampak pada kinerja penjualan, kinerja pemasaran, Interaktivitas dan Peningkatan Jumlah Pegawai serta melihat hambatan penggunaan media sosial oleh pelaku. Riset ini mengisi gap dari riset terdahulu dengan menggunakan lebih banyak responden serta menginventigasi dampak kinerja secara detail. Riset ini ialah pengembangan riset (Purwantini \& Friztina, 2018).

\section{METODE PENELITIAN}

Data yang digunakan dalam penelitian ini yaitu data primer dengan melakukan survey secara langsung kepada pelaku UMKM di Kota Bandar Lampung yang menggunakan media sosial WhatsApp, Instagram, dan Facebook. Sampel dalam survey ditetapkan sebanyak 100 pelaku usaha 
UMKM yang menggunakan media sosial dengan berbagai macam industri di Kota Bandar Lampung. Penyebaran kuesioner kepada pelaku UMKM dilakukan menggunakan google form.

Data yang dikumpulkan di analisis menggunakan metode deskriptif kuantitatif dan deskriptif kualitatif dengan memanfaatkan peralatan statistik deskriptif dan tabel-tabel frekuensi tunggal juga frekuensi silang. Pengambilan keputusan dilihat dari jumlah hasil persentase, jika lebih dari 50\% diartikan variabel tersebut berpengaruh terhadap kinerja UMKM (Lubis dan Junaidi, 2016)

\section{HASIL DAN PEMBAHASAN}

Penelitian ini menggunakan 100 UMKM di Kota Bandar Lampung dengan berbagai macam industri, namun yang terkumpul hanya 98 UMKM sebagai responden dikarenakan 2 responden tidak mengisi kuesioner secara lengkap. Hasil data deskripif responden distribusi frekuensi menunjukkan bahwa 67,30 \% pemilik UMKM berjenis kelamin perempuan dan 32,70\% pemilik UMKM berjenis kelamin Laki-laki. Pendidikan terakhir yang ditempuh oleh pemilik UMKM 60,20\% lulusan Sarjana (S1), di urutan kedua 34,70\% lulusan SMA, 4,10\% lulusan Diploma (D3), dan 1\% lulusan SMP. UMKM yang menjadi reponden 63,30\% berusia 0-5 tahun, 13,30\% berusia 6-10 tahun dan $23,50 \%$ berusia diatas 10 tahun. Sebagian besar pelaku UMKM yang menjadi responden bergerak di bidang dagang sebesar $82,70 \%$, usaha produksi $11,20 \%$, dan jasa $6,10 \%$. Bidang dagang yang ditekuni antara lain fashion, kuliner, kosmetik, parabotan. Sedangkan usaha dibidang produksi yang ditekuni bergerak dibidang pembuatan kopi robusta, pembuatan keripik, pengrajin tapis Lampung, produksi oleh-oleh khas lampung dan usaha jasa anatara lain cukur rambut, sevice komputer, laundry, pencucian mobil dan motor, transportasi.

Tabel 1.

Data deskriptif Responden

\begin{tabular}{|c|c|c|}
\hline Jenis Kelamin & Frekuensi & Persentase \\
\hline Laki-laki & 32 & $32,70 \%$ \\
\hline & 66 & $67,30 \%$ \\
\hline Perempuan & 98 & \\
\hline \multicolumn{3}{|c|}{ Pendidikan Terakhir } \\
\hline SD & 0 & $0 \%$ \\
\hline SMP & 1 & $1 \%$ \\
\hline SMA & 43 & $34,70 \%$ \\
\hline Diploma (D3) & 4 & $4,10 \%$ \\
\hline Sarjana (S1) & 61 & $60,20 \%$ \\
\hline Total & 98 & \\
\hline \multicolumn{3}{|c|}{ Lama Usaha (tahun) } \\
\hline $0-5$ & 62 & $63,30 \%$ \\
\hline $6-10$ & 13 & $13,30 \%$ \\
\hline$>10$ & 23 & $23,50 \%$ \\
\hline Total & 98 & \\
\hline \multicolumn{3}{|l|}{ Jenis Usaha } \\
\hline Jasa & 6 & $6,10 \%$ \\
\hline Dagang & 82 & $82,70 \%$ \\
\hline Produksi & 11 & $11,20 \%$ \\
\hline Total & 98 & \\
\hline
\end{tabular}

Sumber : Data Diolah Penulis, 2021 
Hasil Jenis dan waktu penggunaan media sosial untuk kinerja UMKM menunjukkan bahwa media sosial yang dipakai oleh pelaku UMKM beragam, tetapi hampir seluruh pelaku UMKM menggunakan sosial media yang sama. WhatsApp menjadi aplikasi media sosial yang paling banyak digunakan dengan jumlah $82,70 \%$ dibandingkan media sosial yang lain. Perihal ini disebabkan WhatsApp mempunyai sebagian layanan yang digunakan untuk memasarkan usahanya dengan metode: pertama, pelaku usaha membuat profil usahanya pada bagian data WhatsApp Business semacam penjelasan produk, link web, sosial media lain yang digunakan, sampai jam operasional. Kedua, ada fiture katalog yang mempermudah ada fiture katalog yang mempermudah pelaku UMKM menunjukkan produk serta jasa yang mereka tawarkan. Ketiga, ada pengaturan balasan otomatis, jadi pelakon UMKM tidak butuh repot dalam mengetik perihal sama lagi buat persoalan sama dari pelanggan yang berbeda. Setelah itu urutan kedua media sosial yang kerap digunakan oleh pelaku UMKM ialah Instagram dengan persentase sebesar 69, 40\% serta Facebook sebesar 49\%. Kedua aplikasi ini ialah media sosial yang tidak kalah banyak digunakan oleh para pelaku UMKM sebab banyak dari konsumen yang menggunakan jejaring ini. Pengguna Facebook tidak terbatas usia muda saja, namun pula untuk generasi yang lebih lanjut. Facebook ialah media sosial yang sangat populer serta sangat banyak digunakan oleh sebagian besar warga (Srirejeki, 2016).

Media sosial yang tengah banyak digunakan oleh berbagai kalangan sering kali tidak ada keinginan diawal untuk membeli barang-barang yang mereka inginkan. Namun, seringkali karena adanya promosi produk yang muncul sehingga membuat pelanggan menjadi tertarik untuk melihat dan membeli produk UMKM yang di pasarkan. Pelaku UMKM seringkali menganggap bahwa bisnis yang sedang mereka jalani belum terlalu besar sehingga menggabungkan aplikasi media sosial milik pribadi dengan kepentingan bisnis yang membuat konsumen kurang percaya. Pada riset ini para pelaku UMKM yang menggabungkan media sosial pribadi serta media sosial bisnis tidak dijadikan responden. Lama waktu yang digunakan pelaku UMKM untuk mengakses media sosial dalam sehari 3-4 jam sebesar 33,70\%, urutan kedua 1-2 jam sebesar 27,60\%, urutan ketiga sebesar 21,40\%, dan urutan paling akhir sebesar 17,30\%.

Tabel 2.

Jenis dan waktu penggunaan media sosial oleh pelaku UMKM

\begin{tabular}{ccc}
\hline Media Sosial yang Digunakan & Frekuensi & Persentase \\
\hline Facebook & 48 & $49 \%$ \\
Instagram & 70 & $69,40 \%$ \\
WhatsApp & 82 & $82,70 \%$ \\
Lainnya & 4 & $4,10 \%$ \\
\hline & & \\
\hline waktu yang digunakan (hari) & Frekuensi & Persentase \\
\hline$<1$ jam & 17 & $17,30 \%$ \\
$1-2$ jam & 27 & $27,60 \%$ \\
$3-4$ jam & 33 & $33,70 \%$ \\
$>5$ jam & 21 & $21,40 \%$ \\
\hline
\end{tabular}

Sumber : Data Diolah Penulis, 2021

Popularitas media sosial sudah menghasilkan suatu paradigma baru e-commerce yang diucap social commerce. Social commerce ialah bagian dari e-commerce dengan menggunakan interaksi sosial serta donasi pengguna media sosial dalam berbelanja (Kim \& Park, 2013). Bersumber pada informasi Asosiasi Penyelenggara Jasa Internet Indonesia (APJII), sebagian besar pengguna internet Indonesia menggunakan internet guna mengakses media sosial, hiburan serta online shop. 
Aktivitas perdagangan merupakan kegiatan yang paling banyak dicoba di media sosial ialah sebesar 94, 6\% (APJII, 2016).

Berdasarkan hasil survey yang dilakukan menunjukkan bahwa motivasi para pelaku UMKM menggunakan media sosial dalam memasarkan produk yaitu 77,6 \% menggunakan media sosial untuk menjangkau dan mempromosikan produk mereka secara lebih luas. 73,5\% Promosi produk menjadi lebih mudah dan dapat dilakukan dari mana saja. Kemudian, 69,4\% para pelaku UMKM menggunakan media sosial dikarenakan Transaksi menjadi lebih mudah. 62,2 \% pelaku UMKM mengguanakan media sosial dikarenakan promosi produk menjadi lebih murah tanpa harus membuat brosur, memasang iklan dipinggir jalan, membuka cabang baru dll. Sebagian besar pelaku bisnis UMKM merasakan manfaat promosi produk/ jasa dari aplikasi media sosial. hasil wawancara, inisiatif memakai aplikasi media sosial dalam bisnis UMKM sebagai fasilitas pemasaran produk. Pemakaian aplikasi media sosial yang murah dibanding media konvensional semacam iklan di pesan berita ataupun radio menjadi daya tarik utama.

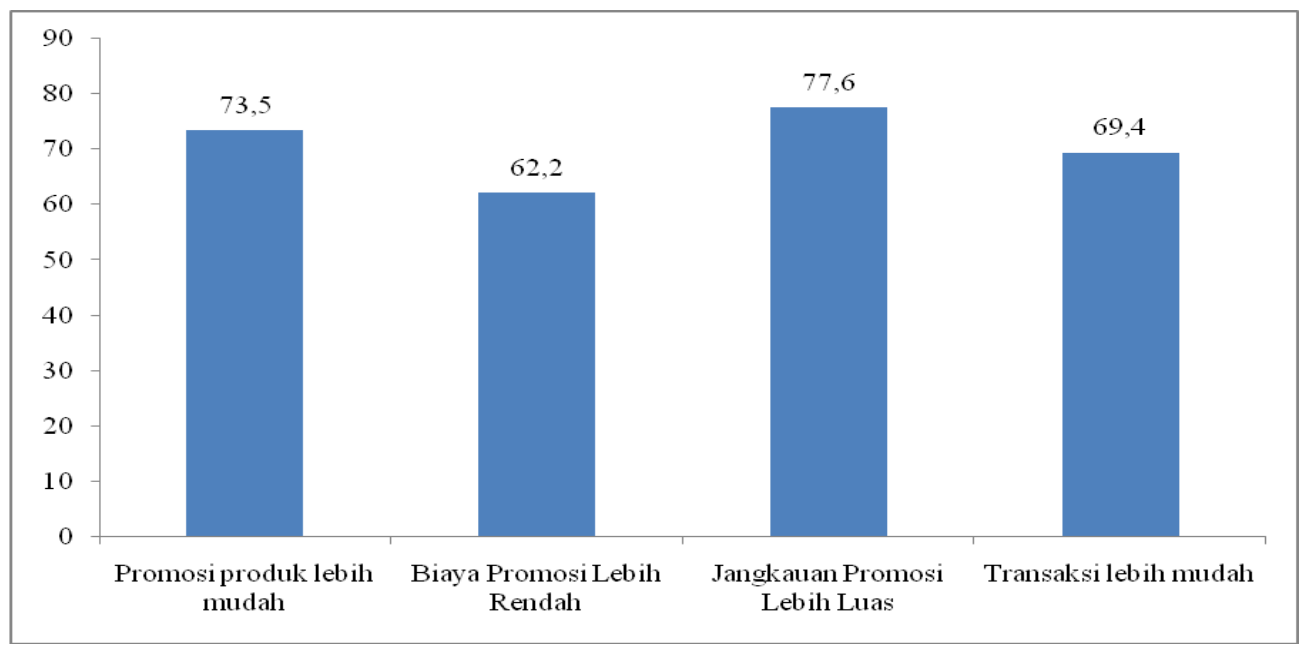

Sumber : Data Diolah Penulis, 2021

Gambar 1.

Motivasi Pelaku UMKM Menggunakan Media Sosial

Pengimplementasian media sosial memberikan dampak pada kinerja penjualan diantaranya peningkatan produksi, meningkatnya omset yang didapat, dan meningkatnya penjualan produk. Banyaknya dampak penggunaan media sosial terhadap kinerja UMKM menjadi salah satu faktor motivasi pelaku UMKM untuk terus memanfaatkan media sosial dalam dalam rangka mengembangkan usahanya, meningkatkan penjualan produk, melakukan komunikasi dengan konsumen, serta mengembangkan jaringan pasar yang lebih luas lagi. hal ini senada dengan penelitian sebelumnya (Alam, 2009), yang menunjukkan bahwa persepsi terhadap manfaat penggunaan teknologi informasi merupakan salah satu faktor pendorong bagi UKM untuk menggunakan media teknologi informasi (Purwidiantoro et al., 2016).

Hasil penelitian pada kinerja penjualan menunjukkan dampak dari penggunaan media sosial 59,2\% terjadi peningkatan penjualan setelah menggunakan media sosial. 57,1\% terjadi peningkatan produksi dibandingkan dengan cara pemasaran konvensional, 56,1 \% omset yang didapatkan oleh pelaku UMKM bertambah. Riset ini memperlihatkan bahwa pemakaian media sosial pada UMKM mampu meningkatkan volume penjuala pada UMKM. Meningkatnya penjualan paling banyak dirasakan UMKM sebesar $>50 \%$. Perihal ini sejalan dengan hasil penelitian sebelumnya yang 
menyebutkan bahwa media sosial adalah sebagai alat pemasaran produk atau jasa selain sebagai wadah interaksi dengan pelanggan untuk mencoba untuk memecahkan masalah mereka sendiri (Edomwan et.a., 2011).

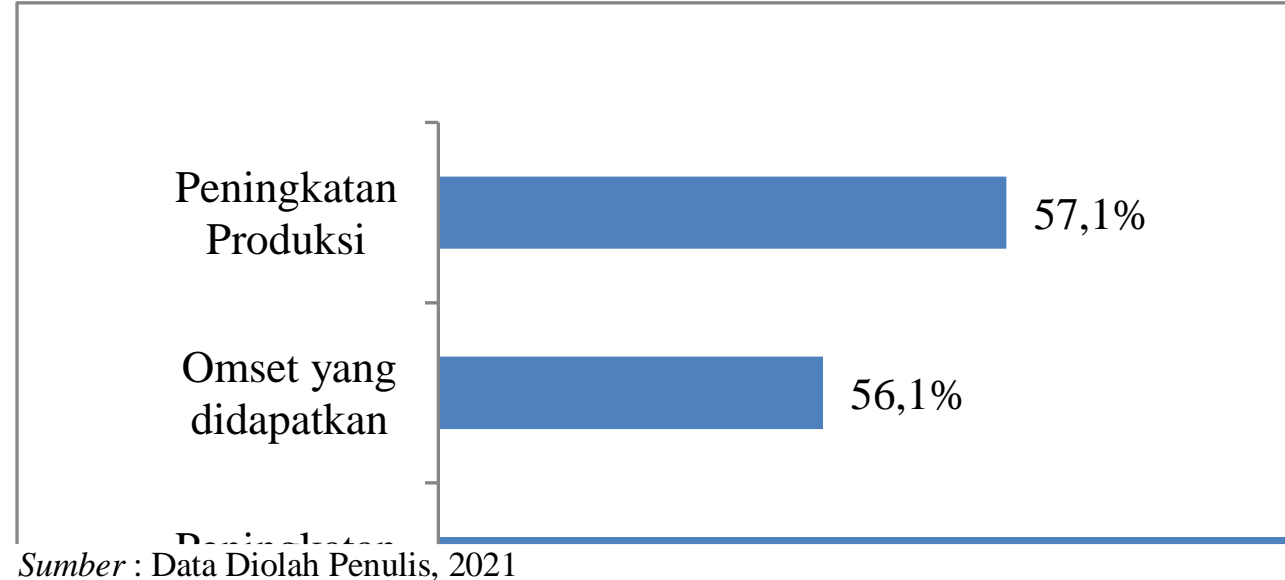

Sumber : Data Diolah Penulis, 2021

Gambar 2.

Media Sosial pada Kinerja Penjualan

Media sosial memberikan dampak pada kinerja pemasaran diantaranya pelanggan yang di jangkau menjadi lebih luas, biaya promosi menjadi lebih rendah, kinerja pemasaran di tunjang dengan informasi produk lebih jelas dengan menggunakan media sosial, fiture yang ada pada media sosial lebih menarik minat pelanggan. Kehadiran media sosial membuat berbagai perusahaan mikro, kecil maupun menengah dapat memasuki pasar global secara mudah dan bahkan bersifat realtime. Semua pelaku bisnis mudah menjalin hubungan suatu bisnis dengan bisnis lainnya, dan memiliki hubungan langsung dengan konsumen (Li \& Hong, 2013).

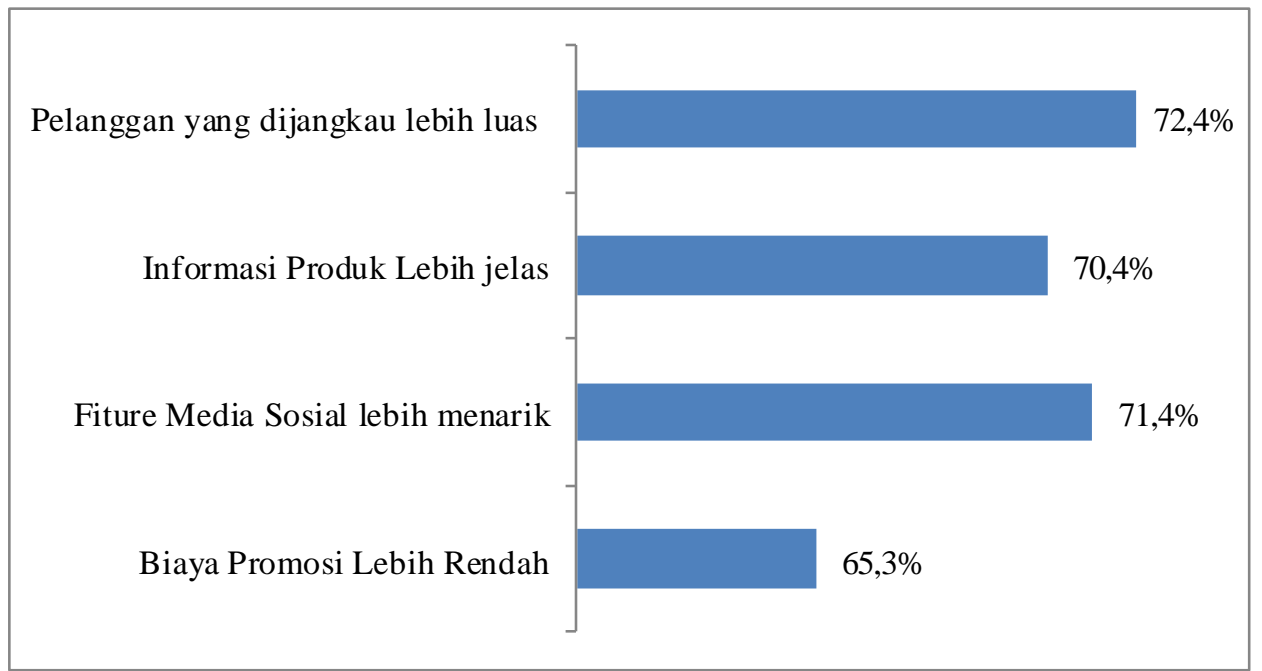

Sumber : Data Diolah Penulis, 2021

Gambar 3.

Media Sosial pada Kinerja Pemasaran 
Hasil penelitian pada kinerja pemasaran menunjukkan dampak dari penggunaan media sosial 72,4\% menjangkau pelanggan yang lebih luas setelah menggunakan media sosial. $71,4 \%$ fiture yang ada pada media sosial membuat produk menjadi lebih menarik sehingga mendukung kinerja pemasaran menjadi lebih mudah, 70,4 \% para pelaku usaha bisa memaparkan informasi produk secara jelas guna menarik minat pelanggan untuk membeli produk yang dipasarkan. $65,3 \%$ biaya promosi menjadi urutan paling bawah namun masih di atas $50 \%$ dibandingkan harus membuat iklan secara konvensional.

Media sosial menjadi fasilitas komunikasi agar dapat berinteraksi, berbagi pengetahuan antar pengguna dalam skala yang luas. Promosi adalah suatu sistem keseluruhan dari kegiatankegiatan bisnis yang ditunjukkan untuk merencanakan, menentukan harga, mempromosikan dan mendistribusikan barang dan jasa untuk memuaskan kebutukan baik kepada pembeli yang ada maupun pembeli yang potensial (Swastha \& Irawan, 2008). Kinerja Interaktivitas yang menjadi salah satu fiture media baru yang paling banyak dibicarakan, mendapatkan tempat khusus di internet. Interaktivitas pengguna media sosial menyebutkan bahwa interaktivitas berarti kemampuan pengguna untuk berkomunikasi secara langsung dengan komputer dan memiliki dampak pada pesan apapun yang sedang dibuat (Fajri, 2017).

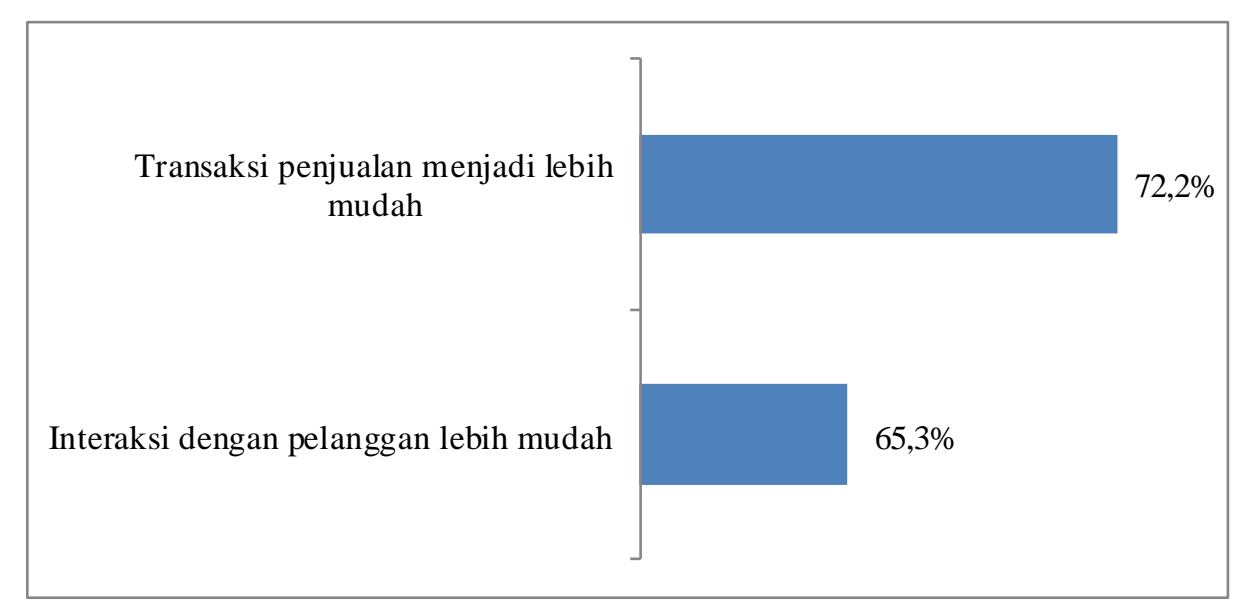

Sumber: Data Diolah Penulis, 2021

\section{Gambar 4. \\ Media Sosial pada Kinerja Interaktif}

Hasil penelitian kinerja Interaktif dampak dari adanya media sosial terhadap kinerja UMKM kota Bandar Lampung 72, $2 \%$ media sosial berdampak pada Transaksi penjualan menjadi lebih mudah dan $65,3 \%$ dengan menggunakan media sosial Interaksi antara pelanggan dengan pelaku UMKM menjadi lebih mudah. Upaya meningkatkan produktivitas suatu industri tidaklah dengan metode bekerja lebih keras, namun bekerja lebih cerdas (Widodo,2015).

Keberhasilan industri atau organisasi dalam meningkatkan produktivitas akan sangat menujang kemampuan bersaing dengan pelaku industri lain. Tuntutan kompetensi di tengah kompetisi hendaknya akan menjadi perihal yang tidak boleh diabaikan. Berbagai aspek dapat berpengaruh pada produktivitas misalnya dari SDM itu sendiri maupun dari luar seperti lingkungan kerja, sarana produksi, dan kesehatan (Sutrisno, 2009).

Hasil penelitian ini terhadap peningkatan jumlah pegawai setelah menggunakan media sosial, 38,8\% kinerja operasional menjadi lebih cepat karena pegawai bertambah. Namun peningkatan jumlah pegawai dampak dari penggunaan media sosial hanya sebesar 33,7\%. Masih kurang dari 50\%. 
Hal ini di artikan dampak penggunaan media sosial terhadap bertambahnya jumlah pegawai masih kurang berpengaruh.

Berdasarkan hasil survey pengguna media sosial terhadap kinerja UMKM di Kota Bandar Lampung baik dilihat dari penggunaan media sosial atau pengelolaan usahanya. Terkait hal tersebut terdapat beberapa faktor-faktor yang hambatan pelaku UMKM yang menggunakan media sosial, diantaranya: (1) Pelanggan dunia maya masih banyak yang kurang percaya untuk belanja online. Kepercayaan dari pelanggan memang menjadi satu hal yang penting dalam bisnis online. Terutama dengan banyaknya isu penipuan online tentu pada akhirnya membuat pelanggan enggan untuk memulai belanja atau menggunakan jasa dari internet. Namun, ketika pelaku UMKM sudah bisa meningkatkan kepercayaan pelanggan, justru tidak sedikit pelanggan yang tidak dapat dipercaya dalam melakukan transaksi pembelian, banyak yang menyalah gunakan media sosial sebagai ajang untuk menipu atau melakukan orderan fiktif. Maka, untuk pelaku UMKM yang menjalankan bisnis ini menjadi salah satu hambatan ketika menggunakan media sosial sebagai sarana untuk berbisnis. (2)Persaingan harga dengan pelaku UMKM lainnya.

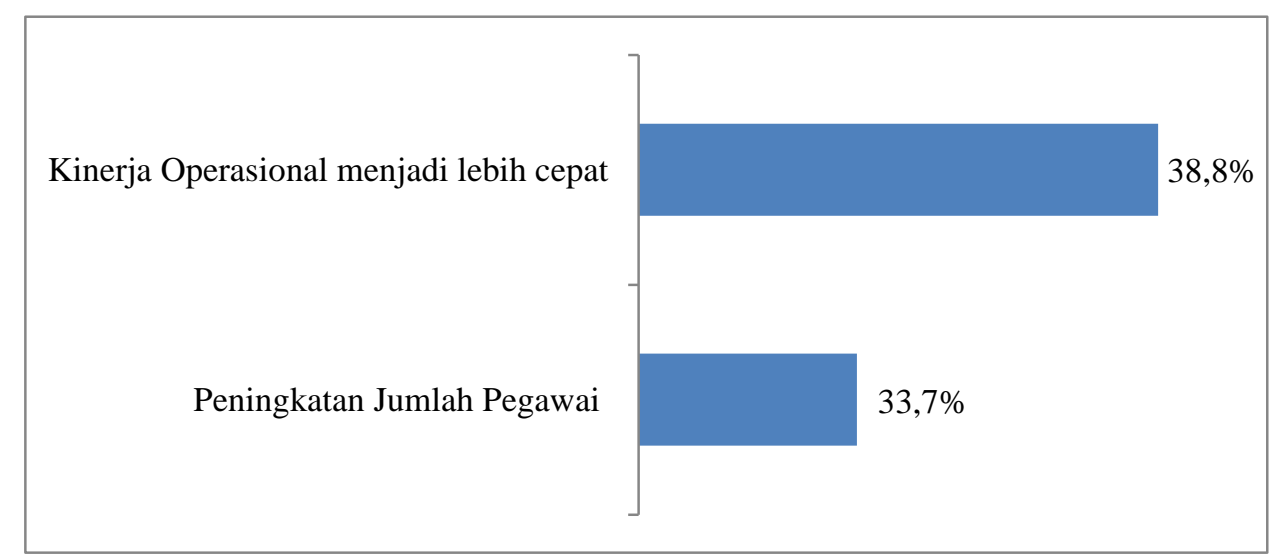

Sumber : Data Diolah Penulis, 2021

Gambar 5.

Media Sosial pada Peningkatan Jumlah Pegawai

Bagi konsumen, belanja online akan sangat tinggi jika mereka merasa puas dengan kualitas jasa, kualitas produk, dan harga yang lebih murah. Hal ini tentu memicu persaingan harga yang begitu ketat antar pelaku UMKM dalam menarik hati pelanggan untuk membeli produk tersebut. Harus selalu menciptakan inovasi baru agar mampu bersaing dengan yang lain. (3) Ongkos kirim. Ongkos kirim menjadi salah satu hambatan yang dirasakan oleh pelaku UMKM yang menggunakan media sosial sebagai sarana untuk berlangsungnya bisnis. Akibat luasnya pelanggan yang dapat dijangkau akibat luasnya promosi menggunakan media sosial tentu berdampak pada jarak tempuh. Semakin jauh jarak tempuh maka akan semakin mahal ongkos kirim yang dibayarkan oleh pelanggan. Dengan mahalnya ongkos kirim tidak sedikit pelanggan yang urung membeli sehingga mencari pelaku UMKM lain yang lebih terjangkau harga dan ongkos kirim sehingga mendapatkan loyalitas dari mereka. (4) Kurangnya pengetahuan tentang Internet Kurangnya pengetahuan tentang internet oleh sebagian masyarakat tentu menjadi hambatan ketika menjalankan UMKM dengan menggunakan media sosial. Maka, tentu harus ada pelatihan untuk menambah pengetahuan tentang media sosial dan internet guna mempermudah transaksi bisnis menggunakan UMKM. 


\section{SIMPULAN DAN SARAN}

Penelitian ini fokus pada dampak penggunaan media sosial terhadap kinerja UMKM terutama media sosial WhatsApp, Instagram dan Facebook. Riset ini menemukan bukti empiris bahwa motivasi pelaku UMKM menggunakan media sosial diantaranya promosi produk menjadi lebih mudah, biaya promosi menjadi lebih murah, jangkauan transaksi menjadi lebih luas dan lebih mudah dengan persentase diatas 50\%. Penelitian menggunakan 98 responden pelaku UMKM yang berada di Kota Bandar Lampung. Hasil dari riset menampilkan jika sebagian besar pelaku UMKM memakai serta menggunakan media sosial selaku fasilitas buat melaksanakan bisnisnya. media sosial dalam bisnis berperan sebagai fasilitas promosi produk/ jasa, memudahkan transaksi, memperoleh pelanggan baru dengan jangkauan yang lebih luas. Hingga, dampak yang di hasilkan media sosial untuk pelaku UMKM di Kota Bandar Lampung ialah meningkatkan kinerja penjualan, meningkatkan kinerja pemasaran, serta interaktif terhadap pelanggan.

Riset ini tidak mengkaji lebih lanjut perbandingan sebelum dan sesudah penggunaan aplikasi media sosial, terkhusus dalam perihal meningkatkan penjualan. Maka disarankan riset lebih lanjut bisa menganalisis perihal tersebut dengan menyamakan apakah ada perbandingan yang signifikan dalam peningkatan penjualan sebelum dan setelah menggunakan media sosial. Hambatan yang dirasakan oleh pelaku UMKM dalam menjalankan bisnis menggunakan media sosial yang paling utama yaitu banyaknya penipuan online yang dilakukan konsumen sehingga membuat pelaku UMKM harus benar-benar berhati-hati dalam menjalankan bisnis menggunakan media sosial.

\section{REFERENSI}

Alam, S.S., dan Noor, M.K.M. (2009). International Journal Of Business and Management. Jakarta: PT Raja Grafindo Persada.

APJII, A. P. J. I. (2016). Penetrasi dan Perilaku Pengguna Internet Indonesia. Infografis Hasil Survey 2016.

Ardianto, Arif. (2018). Analisis Penggunaan Media Sosial Dalam Pengembangan Usaha Mikro, Kecil, Dan Menengah (UMKM) Di Desa Kemasan Kecamatan Sawit Kabupaten Boyolali” (Skripsi). Boyolali: Institut Agama Islam Negeri Surakarta

Cesaroni, F.M., and Consoli, D. (2015). Are small business really able to take advantage of social media Electronic. Journal of Knowledge Management, 13(4), 257-268.

Edomwan, S., Prakasan, S.K., Kouame, D., Watson, J., and Seymour, T. (2011). The History of Social Media and Its Impact on Business. The Journal of Applied Management and Entrepreneurship, 16(3),79-91

Fajri, Jawhari. (2017). Dimensi Interaktif Media Sosial Instagram Instamarinda Guna Memperkenalkan Daerah Pariwisata Di Kota Samarinda. eJ eJournal lmu Komunikasi, 5(3),87-101

Kim, S., and Park, H. (2013). Effects of Various Characteristics of Social Commerce (S-Commerce) on Consumers' Trust and Trust Performance. International Journal Of Information Management, 33(2),318-332.

Li, H., and Hong, J. (2013). Factors Influencing Consumers' Online Repurchasing Behavior. A Review and Research Agenda. iBusiness, 5(4),161-166.

Lubis, Tona Aurora., dan Junaidi. (2016). Pemanfaatan Teknologi Informasi pada Usaha Mikro Kecil dan Menengah di Kota Jambi. Jurnal Persepektif dan Pembangunan Daerah, 3(3), 163-174.

Utami, A. D., dan Purnama, B. E. (2012). Pemanfaatan jejaring sosial sebagai media bisnis online (studi kasus di Batik Solo 85). Seruni FTI UNSA.

Priambada, S. (2015). Manfaat Penggunaan Media Sosial Pada Usaha Kecil Menengah (UKM). Seminar Nasional Sistem Informasi Indonesia, 2-3 November 2015.

Purwanti, Anissa. Hakim., dan Friztina Anisa. (2018). Analisis Pemanfaatan Social Commerce Bagi UMKM: Anteseden Dan Konsekuen. Magelang: Universitas Muhammadiyah Magelang

Purwidiantoro, M. H., S.W, K. D. F., dan Hadi, W. (2016). Pengaruh Penggunaan Media Sosial terhadap Pengembangan Usaha Kecil Menengah (UKM). Jurnal EKA CIDA, 1(1), 30-39.

Siswanto, T. (2013). Optimalisasi Sosial Media Sebagai Media Pemasaran Usaha Kecil Menengah. Liquidity, $2(1), 80-86$. 
Srirejeki, Kiky. (2016) Analysis Of The Use Of Social Media To Empower Small Micro Medium Enterprise (Smes). Jurnal Masyarakat Telematika dan Informasi, 7(1),57-68.

Sutrisno, Edy. (2009). Manajemen Sumber Daya Manusia. Edisi Pertama. Jakarta: Kencana.

Swastha, Basu DH., dan Irawan. (2008). Manajemen Pemasaran Modern. Yogyakarta: Liberty Offset.

Vasileiadou, E.M., and Missler-Behr, M. (2011). Virtual Embeddedness and social media as a basis for the relational capital managemenet of new ventures. The Electronic Journal of Knowledge Management, 9(3), 188-203

Widodo, S. (2015). Manajemen Pengembangan Sumber Daya Manusia. Edisi Pertama. Yogyakarta: Pustaka Pelajar.

Widodo, S. (2015). Manajemen Pengembangan Sumber Daya Manusia. Edisi Pertama. Yogyakarta: Pustaka Pelajar. 